\title{
Fragile X Mental Retardation Protein 1
}

National Cancer Institute

\section{Source}

National Cancer Institute. Fragile X Mental Retardation Protein 1. NCI Thesaurus. Code C75423.

Fragile X mental retardation protein 1 ( $632 \mathrm{aa}, \sim 71 \mathrm{kDa}$ ) is encoded by the human FMR1 gene. This protein plays a role in both translational repression and RNA transport. 